\title{
SASKATCHEWAN NATURAL HISTORY SOCIETY
}

FINANCIAL STATEMENT - YEAR ENDING SEPTEMBER 30, 1970

INCOME

Memberships, including sales of Blue Jay

Spec. Pub. no. 1 - - Guide to Sask. Mammals

Spec. Pub. no. 2 - Birds of the Sask. River

$\$ \quad 58.50$

Spec. Pub. no. 3 - Birds of Regina

Spec. Pub. no. 4 - Blue Jay Index

59.92

56.00

Spec. Pub. no. 5 - Birds of Lake Athabasca

4.00

Spec. Pub. no. 6-Birds of Northeastern Sask.

41.53

Publication - Birds of the Elbow

Bookshop net profit (16.4\% of sales)

31.70

4.06

Donations (general)

505.89

Annual meeting (net)

918.15

34.26

99.88

Summer meeting (net)

214.39

Interest (bank accounts and bonds)

\section{EXPENSE}

Printing of Blue Jay (4 issues)

Advertising and promotion (Newsletter)

$4,658.55$

437.90

490.00

Honoraria: $\$ 300$ and $\$ 190$ (bookshop)

504.57

370.01
92.11

Postage

55.23

65.00

63.59

68.00

Miscellaneous office and admin. expense

Delegate's expense (Canad. Audubon Conference) ......

EXCESS OF INCOME OVER EXPENSE

Statement of Assets and Liabilities as at September 30, 1970 ASSETS

Cash on hand

Cash in bank (current)

$\$ 3,162.90$

Cash in bank (savings) $4,798.81$

Government of Canada bonds

$\$ \quad 40.00$

$7,961.71$

300.00

613.77

186.27

71.77

Accounts receivable (less prepaid orders)

Deposits with Postal Dept. and Sask. Power

Balance of publication subsidy re: Hours and the Birds.

$2,550.33$

Less transfer to net worth account

$2,150.00$

400.33

$9,573.85$

\section{LIABILITIES}

Trust Fund re: Refuge and Sanctuary

Balance at September 30, 1969

Plus donations during past year

$\$ 1,766.49$

50.00

$1,816.49$

NET WORTH

Balance at September 30, 1969

Surplus September 30, 1970

Refund from YNHS

$\$ 2,493.44$

$7,744.64$

(to cover Cliff Shaw annual award)

130.66

$2,624.10$

$10,368.74$

Less: Hours and the Birds transfer.

$2,150.00$

Less adjustment re: 1967-68 honorarium. 


\section{THE SASKATCHEWAN NATURAL HISTORY SOCIETY}

BOARD OF DIRECTORS (October, 1970, to October, 1971

Honorary President.

Robert D. Symons, Silton, Saskatchewan

President Gordon Silversides, 1201 Grace Street, Moose Jaw

Past President

W. A. Brownlee, 3628 Mason Avenue, Regina

First Vice-President J. A. Wedgwood, 610 Leslie Avenue, Saskatoon

Second Vice-President. Margaret Belcher, 2601 Winnipeg Street, Regina

Treasurer George R. Dodd, 33 Malone Crescent, Regina

Corresponding Secretary ... Patricia Kern, 1053 Chestnut Street, Moose Jaw

Recording Secretary Marie Gillespie, 221 Eleventh Street E., Saskatoon

\section{REPRESENTATIVES AT LARGE}

Ron Austin, Prince Albert; Harvey Beck, Calgary; Al Binnie, Regina; Tom Gentles, Regina; Donald Hayward, Wolseley; Ernie Kuyt, Fort Smith, N.W.T.; Jack McKenzie, Regina; Murdoch Nelson, Moose Jaw; Frank Roy, Saskatoon; Charles Shulver, Lafleche; Mary Skinner, Indian Head; Mrs. Sylvia Van Brienen, Rosetown.

\section{PRESIDENTS OF LOCAL NATURAL HISTORY SOCIETIES}

Mrs. D. Bromey, Maple Creek; Carl Ellis, Moose Jaw; Dr. G. B. Howard, Prince Albert; Mrs. E. Weisbrot, Regina; Ewen Coxworth, Saskatoon; Dr. Jan Looman, Swift Current; Bill Gibson, Yorkton.

\section{APPOINTED DIRECTORS}

Blue Jay Archives: Gary Seib, 1928 Robinson Street, Regina; Blue Jay Bookshop: Frank Brazier, 2657 Cameron Street, Regina; Circulation: Lorne Scott, Saskatchewan Museum of Natural History, Regina; Editor of Newsletter: James Slimmon, 2526 Hanover Avenue, Saskatoon; Local Societies: James Wedgwood, 610 Leslie Avenue, Saskatoon; Office Services: James Jowsey, 2635 Nineteenth Avenue, Regina; Publicity: Rose McLaughlin, Indian Head; Special Publications: C. Stuart Houston, 863 University Drive, Saskatoon; Youth: Frank Switzer, 140 Logan Crescent, Yorkton.

\section{THE BLUE JAY}

Blue Jay Editors: George F. Ledingham; Assistant Editors: Margaret Belcher, Robert W. Nero; Junior Naturalists: Joyce Deutscher.

All items for publication should be submitted to George F. Ledingham, Editor, 2335 Athol Street, Regina.

\section{SUBSCRIPTION-MEMBERSHIPS}

The classes of memberships in the SNHS are as follows: Regular, $\$ 3.00$; Supporting, $\$ 5.00$; Sustaining $\$ 10.00$. Bulk orders (minimum of five to one address) are available to junior club members and to educational institutions at the rate of $\$ 3.00$ for the first subscription and $\$ 1.00$ for each additional one.

Send all renewals and new memberships to THE TREASURER, SNHS, Box 1321, Regina, Saskatchewan. (Note: Bookshop orders and general inquiries should be sent to Box 1121.)

\section{REPRINTS}

Requests for quantities of reprints of any article printed in the Blue Jay should be sent to Printcraft Ltd., Regina, Sask., within one month of publication. Contributors wishing a few extra copies of the current Blue Jay may get them at cost. Requests for these should be made to the Editor when material is submitted for publication. 